\title{
MOTIVASI MENGIKUTI PEMBELAJARAN PENDIDIKAN JASMANI, OLAHRAGA DAN KESEHATAN PESERTA DIDIK SMA/SMK DI KECAMATAN RENDANG DI MASA PANDEMI COVID-19
}

\author{
Kadek Satria Kustria ${ }^{1}$, I Gusti Lanang Agung Parwata ${ }^{2}$, Ni Luh Putu Spyanawati ${ }^{3}$ \\ Prodi Pendidikan Jasmani Kesehatan dan Rekreasi \\ Jurusan Pendidikan Olahraga \\ Fakultas Olahraga dan Kesehatan \\ Universitas Pendidikan Ganesha \\ Email : kustrias@gmail.com', agung.parwata@undiksha.ac.id², \\ putu.spyanawati@undiksha.ac.id ${ }^{3}$
}

\begin{abstract}
ABSTRAK
Penelitian ini bertujuan untuk menganalis motivasi mengikuti pembelajaran Pendidikan Jasmani, Olahraga dan Kesehatan peserta didik SMA/SMK di Kecamatan Rendang di masa pandemik covid-19. Penelitian ini merupakan penelitian deskriptif kuantitatif dan metode dalam penelitian ini adalah metode survei. Populasi dalam penelitian ini seluruh peserta didik di SMA/SMK di Kecamatan Rendang dengan jumlah populasi 1.257 orang dan di pilih kelas secara random sampling. Sampel penelitian ini berjumlah 253 orang. Data dianalisis menggunakan statistik dengan persentase. Hasil penelitian ini menunjukan bahwa motivasi mengikuti pembelajaran Pendidikan Jasmani, Olahraga dan Kesehatan peserta didik SMA/SMK di Kecamatan Rendang di masa pandemik covid-19 yaitu berada dalam kategori tinggi yaitu 78 orang $(30,83 \%)$. Disarankan bahwa agar kedepannya guru Pendidikan Jasmani, Olahraga dan Kesehatan dapat mengemas proses pembelajaran di masa pandemik covid-19 lebihbaik dan bervariatif dalam melaksanakan proses pembelajaran daring.
\end{abstract}

Kata kunci: motivasi, pembelajaran PJOK, pandemi covid-19.

\begin{abstract}
The aimed of this study was to analyze the motivation to attend the Sport, Physical Education and Health course of SMA/SMK students in Rendang district in this covid-19 pandemic. This study was descriptive quantitative researchwith survey method used. The populations of this study were all of the students in Rendang district with the total amount 1.257 students and chosen by random sampling. The sample of this study were 253 students. The used of data analysis is statistic with percentage. The result of this study showed that motivation attending Sport, Physical Education and Health course Students SMA/SMK in Rendang district in this covid-19 pandemic is in high category by 78 students $(30,83 \%)$. Suggested that Sport, Physical Education and Health can package learning process in this pandemic to be better and more varied in implementing online learning process.
\end{abstract}

Keywords: Motivation, PJOK Course, Covid-19 Pandemic 


\section{PENDAHULUAN}

Pendidikan merupakan hal yang penting karena dengan pendidikan dapat mengembangkan pontensi sumber daya manusia. Potensi-pontensi tersebut meliputi kecerdasan intelektual, sosial, spiritual dan keterampilan yang dibutuhkan dalam memenuhi kebutuhan sebagai manusia. Hartono, dkk dalam (Tri Wibowo, n.d.) menyatakan bahwa pendidikan Jasmani, Olahraga dan Kesehatan adalah proses pendidikan yang memanfaatkan aktivitas fisik untuk membugarkan dan menghasilkan perubahan holistik dalam kualitas individu, baik dalam hal fisik, mental, serta emosional. Untuk dapat mencapai tujuan tersebut maka guru harus memiliki strategi atau gaya mengajar yang interaktif, menyenangkan, menantang dan memotivasi peserta didik.

M. A. Setiawan, (1999) yang menyatakan bahwa pembelajaran adalah kegiatan guru secara terprogram dalam desain intruksional untuk membuat peserta didik belajar secara aktif, yang menekankan pada penyediaan sumber belajar. Model pembelajaran dapat ditentukan oleh guru atau dosen dengan memperhatikan tujuan dan materi pembelajaran yang akan diajarkan merujuk pada situasi dan kondisi yang terjadi di sekolah Jayul\& Irwanto, (2020). Guru sebagai tenaga pendidik professional bertugas merencanakan dan melaksanakan pembelajaran, menilai hasil pembelajaran, melakukan pembimbingan dan pelatihan, melakukan penelitian, membantu pengembangan dan pengelolaan program sekolah serta mengembangkan profesionalitasnya Depdiknas, 2004 (dalam Arifianto \& Raibowo, 2020).

Salah satu mata pelajaran yang ada di sekolah adalah pelajaran Pendidikan Jasmani, Olahraga dan Kesehatan. Pendidikan Jasmani, Olahraga dan Kesehatan menitik beratkan pada proses pembelajaran melalui aktifitas jasmani yang di desain untuk meningkatkan kebugaran jasmani, mengembangkan keterampilan motorik pengetahuan dan prilaku sehat dan aktif, sikap sportif, dan kecerdasan emosi (Samsudin, 2008). Pendidikan Jamani Olahraga dan Kesehatan merupakan media untuk mendorong perkembangan keterampilan motorik, kemampuan fisik, pengetahuan, penalaran penghayata nilai (sikap, mental, emosional, spiritual, sosial), dan pembiasaan pola hidup sehat untuk merangsang pertumbuhan.

Seperti saat ini yakni karena adanya pandemi covid-19 yang diaman virus ini memiliki RNA strain tunggal positif, berkapsul dan tidak bersegmen. Coronavirus tergolong ordo Nidovirales, keluarga Caoronaviridae yang mengharuskan pembelajaran dilaksanakan dengan daring. Menurut Mustofa et al., (2019) pembelajaran daring adalah sistem pembelajaran jarak jauh melalui beberapa metode pengajaran, namun aktivitas pengajaran yang dilakukan secara terpisah dari aktivitas belajar. Sedangkan menurut Imania \& Bariah, (2019) menjelakan pebelajaran daring adalah proses pebelajaran yang interaksinya dihubungkan oleh internet. Merujuk pada beberpa pada penjelasan pembelajaran daring di atas, maka pebelajaran daring dapat diartikan sebagai sebuah proses pembelajaran dengan bantuan internet sebagai penghubung interaksi antara guru dengan peserta didik dan peserta didik dengan peserta didik.

Salah satu mata pembelajaran yang dilakukan secara daring adalah Pendidikan Jasmani, Olahraga dan Kesehatan (PJOK). PJOK merupakan suatu proses pembelajaran melalui aktivitas jasmani dengan berpartisipasi dalam akitvitas fisik, dengan melakukan aktivitas jasmani siswa dapat mengembangkan apresiasi estetis, dengan menguasai keterampilan dan pengetahuan, mengembangkan keterampilan generik serta nilai dan sikap 
yang positif, dan memperbaiki kondisi fisik. Menurut Muhammad et al., (2020) Pendidikan Jasmani, Olahraga dan Kesehatan merupakan aktivitas jasmani yang dirancang dan disusun secara sistematik untuk merangsang pertumbuhan dan perkembangan serta pembentukan karakter dalam rangka mencapai tujuan pendidikan.

Kebijakan belajar di rumah dilaksanakan dengan tetap melibatkan pendidik dan peserta didik melalui Pembelajaran Jarak Jauh Arifa, (2020). Kondisi pandemi saat ini menuntut pendidik dalam hal ini adalah guru untuk berinovasi menggubah pola pembelajaran tatap muka menjadi pola pembelajaran tanpa tatap muka (Anugrahana, 2020).

Dan saat ini ada beberapa teknologi informasi yang dapat dimanfaatkan sebagai media pembelajaran diantaranya dengan menggunakan e-learning. Elearning merupakan inovasi yang dapat dimanfaatkan dalam proses pembelajaran, tidak hanya dalam penyampaian materi pembelajaran tetapi juga perubahan dalam kemampuan berbagai kompetens peserta didik. Melalui e-learning, peserta didik tidak hanya mendengarkan uraian materi dari pendidik saja tetapi juga aktif mengamati, melakukan, mendemonstrasikan, dan sebagainya (Pakpahan\& Fitriani, 2020).

Tidak hanya itu guru harus pandai dalam memilih dan menerapkan strategi serta metode pembelajaran yang paling tepat, agar pembelajaran menjadi efektif dan menyenangkan (Oknisih et al., 2019).

Namun pada penerapannya dilapangan, pembelajaran jarak jauh memiliki beberapa kendala, meliputi: 1) guru mengalami kendala pada pemanfaatan aplikasi pembelajaran, pengelelolaan, pengawasan dan penilaian pembelajaran (Rigianti, 2020; Sadikin \& Hamidah, 2020), 2) peserta didik merasa cemas dalam mengikuti pebelajaran akibat mereka kurang memahami materi yang dibahas (Oktawirawan, 2020), 3) guru sering mengalami kendala dalam meningkatkan motivasi dan mengembangkan kreativitas selama melaksanakan pemmbelajaran daring (Nopiyanto dkk., 2020).

Didalam masa pandemi covid-19 ini dimana semua aktivitas pembelajaran dilakukan di rumah melalui daring dan dari hasil observasi awal yang telah di lakukan di kecamatan Rendang memiliki satu SMA dan satu SMK yakni SMA Negeri 1 Rendang dan SMK Giri Pandawa untuk mengetahui motivasi peserta didik dalam pembelajaran PJOK di masa pandemic covid-19. Hasil temuan awal berdasarkan hasil wawancara dengan dua guru mata pelajaran olahraga di sekolah yang berbeda yakni yang pertama bersama bapak I Kadek Sentana Adi Putra, S.Pd selaku salah satu guru olahraga di SMA Negeri 1 Rendang. Yang kedua berdasarkan hasil wawancara dengan bapak I Wayan Suryana Arimbawa, S,Pd selaku salah satu guru olahraga di SMK Giri Pandawa. Guru menyatakan bahwa masih belum mengetahui seberapa besar motivasi peserta didik dakam mengikuti pembelajaran Pendidikan Jasmani, olahraga dan Kesehatan di karenakan guru belum melakukan penelitian mengenai motivasi peserta didik dalam pembelajaran PJOK di masa pandemi covid-19.

M., (2016) Istilah motivasi berasal dari kata "motif", diartikan sebagai daya upaya yang mendorong seseorang untuk malukan sesuatu. Motif dapat dikatakan sebagai daya penggerak dari dalam dan dan didalam subjek untuk melakukan aktivitas-aktivitas tertentu demi mencapai suatu tujuan. Dalam belajar, motivasi merupakan hal yang sangat penting. Motivasi dapat juga dikatakan serangkaian usaha untuk menyediakan kondisi-kondisi tertentu sehingga seseoarang mau dan ingin melakukan sesuatu, dan bila ia tidak suka, maka akan berusaha untuk meniadakan atau mengelakan perasaan tidak suka itu, jadi motivasi itu dapat dirangsang oleh faktor 
dari luar tetapi motivasi itu adalah tumbuh di dalam diri seseorang. Makin tepat motivasi yang di berikan, akan makin berhasil pula pelajaran itu. Sedangkan motivasi, menurut Mc Donald (dalam Cahyani et al., 2020)) adalah suatu perubahan energi yang terjadi pada individu yang ditandai dengan timbulnya perasaan dan reaksi atau tindakan untuk mencapai tujuan tertentu.

Dalam hubungan motivasi dengan kegiatan belajar yang terpenting adalah bagaimana manciptakan kondisi atau suatu proses yang mengarahkan siswa untuk melakukan aktivitas belajar dan bagaimana guru juga melakukan usahausaha untuk dapat menumbuhkan dan memberikan motivasi agar siswa melakukan aktivitas belajar yang baik (Jasmani et al., n.d.).

Strategi yang digunakan oleh guru sangat berperan dalam upaya meningkatkan dan motivasi peserta didik dalam suatu proses pembelajaran, yaitu dengan memberikan stimulus untuk menciptakan suatu kondisi pembelajaran yang menarik, memberikan dorongan untuk tindakan yang bertujuan dengan arah yang diinginkan. Baik fisik maupun mental, sehingga aktivitas menjadi bagian yang sangat penting dalam motivasi (Fitriyani et al., 2020).

Melihat fenomena yang terjadi, maka sangat penting dilakukan suatu penelitian mengenai motivasi peserta didik di SMA/SMK Kecamatan Rendang dalam mengikuti pembelajaran Pendidikan Jasmani, Olahraga dan Kesehatan di dalam masa pandemi covid19, guna untuk mengetahui motivasi peserta didik di SMA/SMK Kecamatan Rendang dalam mengikuti pembelajaran Pendidikan Jasmani, Olahraga dan Kesehatan di masa pandemi covid-19. Penelitian ini penting dilakukan karena akan bermanfaat bagi sekolah, perguruan tinggi, maupun masyarakat umum.

Motivasi sangat penting dimiliki peserta didik dalam proses pembelajaran. motivasi baik intrinsik maupun ekstrinsik harus ada pada diri siswa sehingga tujuan pembelajaran yang sudah dirumuskan dapat tercapai secara optimal (Emda, 2018). Hasil penelitian (Eka et al., 2020); Hendri,Gus.Aziz, (2020)., Saputra et al., (2018); Sulfemi (2019); Fauziah dkk., (2017) menunjukan bahwa adanya hubungan yang positif antara motivasi belajar peserta didik dengan hasil belajarnya. Semakin tinggi motivasi belajarnya semakin tinggi pula hasil belajarnya.

\section{METODE PENELITIAN}

Penelitian ini menggunakan metode penelitian deskriptif kuantitatif. Populasi dalam penelitian ini, populasi mencangkup seluruh peserta didik kelas X, XI dan XII di SMA/SMK Kecamatan Rendang yang berjumlah 1.257 peserta didik. Dalam penentuan sample penelitian mengunakan teknik sample random sampling yaitu: digunakan apabila populasi homogeny.

Setelah dilaksanakan pengambilan sampel penelitian ini didapat 15\% / $100 \mathrm{X}$ $849=127$, jadi sampel yang digunakan dalam penelitian ini untuk di SMA $\mathrm{N} 1$ Rendang sebanyak 127 peserta didik dan untuk di SMK Giri Pnadawa pengambilan sampel dalam penelitian ini adalah $31 \%$ dari populasi yang ada di SMK Giri Pandawa Berati 31\%/ $100 \times 408=126$, jadi sampel yang digunakan dalam penelitian ini untuk di SMK Giri Pandawa sebanyak 126 peserta didik. Dari hasil di atas, jumlah total sampel penelitian adalah 253 peserta didik SMA di Kecamatan Rendang.

Variabel dalam penelitian ini adalah motivasi peserta didik SMA/SMK di Kecamatan Rendang dalam mengikuti pembelajaran Pendidikan Jasmani, Olahraga dan Kesehatan di masa pandemi covid-19.

Metode dalam pengumpulan data yang digunakan dalam penelitian ini meliputi metode observasi, metode wawancara, metode angket/kuisioner. 
Penyebaran kuisioner dilakukan dengan menggunakan bantuan google form yang disebarkan melalui grup belajar kelas di setiap sekolah. Sedangkan metode penunjang pengambilan data dalam penelitian ini adalah metode dokumentasi.

Metode observasi yang dilakukan dalam penelitian ini adalah metode yang berisi sebuah proses pengamatan yang dilakukan seorang peneliti untuk memperoleh pedoman yang digunakan untuk memperoleh data. Selanjutnya, dalam metode wawancara dapat di bagi menjadi dua jenis, yaitu wawancara terstruktur dan wawancara tidak terstruktur. Jenis wawancara yang digunakan dalam penelitin ini adalah wawancara tidak terstruktur. Sedangkan metode angket pada umumnya meminta keterangan tentang fakta yang diketahui oleh responden atau juga mengenai pendapat atau sikap. Angket ini digunakan untuk memperoleh data mengenai motivasi peserta didik dalam mengikuti pembelajaran Pendidikan Jasmani, Olahraga dan Kesehatan SMA di Kecamatan Rendang dalam pembelajaran daring. Metode dokumentasi merupakan kegiatan untuk menyimpan ataupun mengabadikan suatu peristiwa. Dalam penelitian ini metode dokumentasi digunakan untuk mengabadikan kegiatan penelitian mengenai motivasi peserta didik mengikuti pembelajaran PJOK dalam pembelajaran daring.

Dalam penelitian ini instrument yang akan digunakan adalah angket/kuisioner yang terdiri dari pernyataan positif dan negative. Tingkat kesetujuan responden diklasifikasikan sebagai berikut: : Sangat Setuju (SS), Setuju (S), Tidak Setuju (TS), dan Sangat Tidak Setuju (STS) yang digunakan untuk mengungkapkan motivasi peserta didik dalam pembelajaran Pendidikan Jasmani, Olahraga dan Kesehatan di masa pandemic covid-19 saat ini yang ditinjau dari faktor intrinsik (daya tarik, perhatian, aktivitas) dan faktor ekstrinsik (lingkungan dan alat/fasilitas).

Teknik analisi data yang dugunakan adalah analisis data diskriptif dengan persentase dari jawaban peserta didik. Penghitungan statistik deskriptif menggunakan statistik deskriptif persentase, karena yang termasuk dalam statistik deskriptif antara lain penyajian data melalui tebel, grafik, perhitungan mean, median, perhitungan penyebaran data perhitungan rerata-rata skor, stadar devisiasi, dan persentase. Pengkategorian menggunakan Mean dan Standar Deviasi.

\section{HASIL DAN PEMBAHASAN}

\section{Hasil Penelitian}

Penelitian ini dilakukan di dua sekolah yakni di SMA Negeri 1 Rendang dan di SMK Giri Pandawa yang berada di desa Rendang, Kecamatan Rendang, Kabupaten Karangasem, Provinsi Bali. Penelitian ini dilaksanakan dari bulan Agustus sampai bulan September 2020. Adapun waktu pengambilan data dilaksanakan selama 11 hari yaitu dari tanggal 24 Agustus sampai dengan 3 September 2020. penelitian ini melibatkan seluruh peserta didik di SMA/SMK di Kecamatan Rendang adapun jumlah populasi dalam penelitian ini dari kedua sekolah yakni 1.257 peserta didik anatara lain 849 peserta didik di SMA Negeri 1 Rendang dan 408 peserta didik di SMK Giri Pandawa, dan mendapatkan sampel sebanyak 253 peserta didik yang terbagi dalam dua sekolah antara lain 127 peserta didik di SMA Negeri 1 Rendang dan 126 peserta didik di SMK Giri Pandawa.

Pengambilan sampel pada penelitian di ambil dari masing-masing angkatan di setiap sekolah antara lain pada SMA Negeri 1 Rendang di kelas $X$ di peroleh 35 peserta didik, kelas XI 33 peserta didik dan kelas XII 59 peserta didik sedangkan pada SMK Giri Pandawa di kelas $X$ di dapatkan 33 peserta didik, 
kelas XI 39 peserta didik dan kelas XII 54 peserta didik. Pengambilan data pada penelitian ini di laksanakan dengan teknik daring dengan menggunakan bantuan google form.

Hasil penelitian ini diperoleh melalui kuesioner yang diisi oleh setiap responden. Untuk mempermudah penyajian data penelitian, maka data motivasi sebelum dianalisis perlu dideskripsikan. Terdapat beberapa faktor yang diamati terhadap motivasi dalam pembelajaran Pendidikan Jasmani, Olaharaga dan Kesehatan di masa pandemi covid-19 yaitu faktor pengetahuan, perhatian, minat, guru, teman, sarana prasarana dan orang tua. Berikut adalah hasil dari analisis deskritif data motivasi peserta didik di SMA/SMK mengikuti pembelajaran PJOK di masa pandemi covid-19.

Tabel 1. Deskripsi Analisis Data Motivasi Hasi Penelitian SMA N 1 Rendang

\begin{tabular}{llllll}
\hline No & Data & Minimum & Maksimum & Rata-rata & $\begin{array}{c}\text { Standar } \\
\text { Deviasi }\end{array}$ \\
\hline 1 & Pengetahuan & 4 & 8 & 6,30 & 0,95 \\
2 & Perhatian & 2 & 8 & 5,82 & 1,25 \\
3 & Minat & 5 & 12 & 9,31 & 1,49 \\
4 & Guru & 4 & 8 & 6,52 & 0,89 \\
5 & Teman & 2 & 8 & 5,12 & 1,12 \\
6 & Sarana prasarana & 2 & 8 & 6,25 & 1,43 \\
7 & Orang tua & 4 & 8 & 6,03 & 1,06 \\
\hline
\end{tabular}

Hasil analisis deskriptif data motivasi peserta didik terhadap pembelajaran Pendidikan Jasmani,
Olaharaga dan Kesehatan di masa pandemi covid-19 di SMK Giri Pandawa adalah sebagai berikut:

Tabel 2. Deskripsi Analisis Data Motivasi Hasil Penelitian SMK Giri Pandawa

\begin{tabular}{llllll}
\hline No & Data & Minimum & Maksimum & Rata-rata & Standar Deviasi \\
\hline 1 & Pengetahuan & 4 & 8 & 6,68 & 0,94 \\
2 & Perhatian & 2 & 8 & 5,91 & 1,22 \\
3 & Minat & 5 & 12 & 9,62 & 1,53 \\
4 & Guru & 5 & 8 & 6,73 & 0,79 \\
5 & Teman & 3 & 8 & 6,12 & 1,39 \\
6 & Sarana prasarana & 4 & 8 & 6,81 & 1,01 \\
7 & Orang tua & 3 & 8 & 6,25 & 1,34 \\
\hline
\end{tabular}

Data dalam penelitian motivasi peserta didik SMA Negeri 1 Rendang terhadap pembelajaran Pendidikan, Jasmani, Olaharaga dan Kesehatan di masa pandemi covid-19 dianalisis menggunakan teknik statistic deskriptif. Teknik perhitungan yang dilakukan menggunakan presentase Motivasi peserta didik SMA Negeri 1 Rendang terhadap pembelajaran Pendidikan, Jasmani, Olaharaga dan Kesehatan di masa pandemi covid-19 telah diukur menggunakan angket yang terdiri dari 15 butir pertanyaan. Dari hasil analisis data yang telah dilakukan, terhadap motivasi peserta didik, maka diperoleh rerata sebesar 44,00, median sebesar 46,00. mode sebesar 49,00 dan standar deviasi ideal sebesar 3,67. Distribusi frekuensi pengkategorian dapat dilihat sebagai berikut. 
Tabel 3. Motivasi Peserta Didik SMA Negeri 1 Rendang Terhadap Pembelajaran Pendidikan, Jasmani, Olaharaga dan Kesehatan di Masa Pandemi Covid-19.

\begin{tabular}{|c|c|c|c|}
\hline Interval & Kategori & Frekuensi (Orang) & Presentase (\%) \\
\hline$X>49.50$ & ST & 19 & $14,96 \%$ \\
\hline $45.83<X<49.50$ & $\mathrm{~T}$ & 45 & $35,43 \%$ \\
\hline $42.17<X<45.82$ & S & 29 & $22,83 \%$ \\
\hline $38.50<X<42.17$ & $\mathrm{R}$ & 22 & $17,32 \%$ \\
\hline $38.50<X$ & SR & 12 & $9,46 \%$ \\
\hline \multicolumn{2}{|c|}{ Total } & 127 & $100 \%$ \\
\hline
\end{tabular}

Apabila dilihat dari data jumlah yang muncul dari setiap kategori atau jumlah peserta didik yang mencul pada tiap kategori, maka dapat diketahui bahwa motivasi peserta didik SMA Negeri 1 Rendang terhadap motivasi pembelajaran Pendidikan, Jasmani, Olaharaga dan Kesehatan di masa pandemi covid-19 berada dalam kategori tinggi. Menurut Suprihatin (2019) untuk menumbuhkan motivasi belajar siswa yaitu dengan mengembangkan kemampuan serta keinginan dari siswa dalam mengikuti pelajaran.

Data dari hasil analisis motivasi peserta didik SMA Negeri 1 Rendang mengikuti pembelajaran Pendidikan Jasmani, Olahraga dan Kesehatan dalam pembelajaran daring dapat dilihat pada gambar berikut:

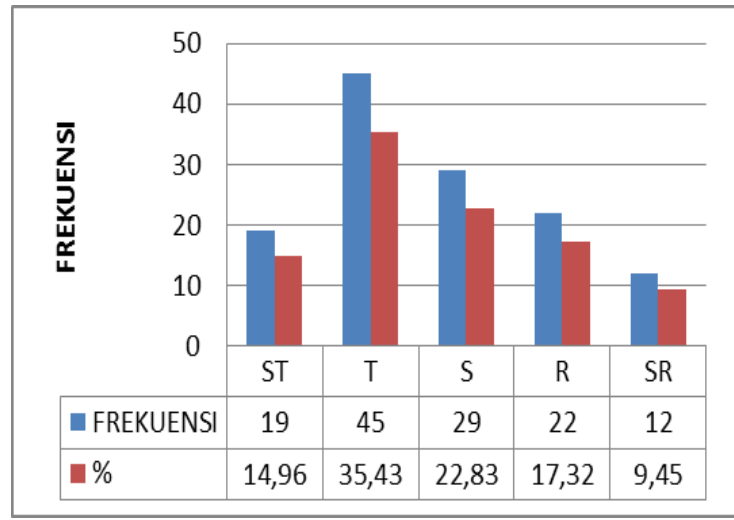

Gambar 1. Grafik Motivasi Peserta Didik SMA Negeri 1 Rendang Terhadap Pembelajaran Pendidikan, Jasmani, Olaharaga dan Kesehatan di Masa Pandemi Covid-19

Data dalam penelitian motivasi peserta didik SMK Giri Pandawa terhadap pembelajaran Pendidikan, Jasmani, Olaharaga dan Kesehatan di masa pandemi covid-19 dianalisis menggunakan teknik statistic deskriptif. Teknik perhitungan yang dilakukan menggunakan presentase.

Motivasi peserta didik SMK Giri Pandawa terhadap pembelajaran Pendidikan, Jasmani, Olaharaga dan Kesehatan di masa pandemi covid-19 telah diukur menggunakan angket yang terdiri dari 15 butir pertanyaan. Dari hasil analisis data yang telah dilakukan, terhadap motivasi peserta didik, maka diperoleh rerata sebesar 46,50, median sebesar 45,00, mode sebesar 51,00 dan standar deviasi ideal sebesar 3,50. Distribusi frekuensi pengkategorian dapat dilihat sebagai berikut. 
Tabel 4. Motivasi Peserta Didik SMK Giri Pandawa Terhadap Pembelajaran Pendidikan, Jasmani, Olaharaga dan Kesehatan di Masa Pandemi Covid-19

\begin{tabular}{|c|c|c|c|}
\hline Interval & Kategori & Frekuensi (Orang) & Presentase (\%) \\
\hline$X>51,75$ & ST & 38 & $30,16 \%$ \\
\hline $48,25<X<51,75$ & $\mathrm{~T}$ & 27 & $21,43 \%$ \\
\hline $44,75<X<48,25$ & $S$ & 28 & $22,22 \%$ \\
\hline $41,25<X<44,75$ & $\mathrm{R}$ & 13 & $10,32 \%$ \\
\hline $41,25<X$ & SR & 20 & $15,87 \%$ \\
\hline \multicolumn{2}{|l|}{ Total } & 126 & $100 \%$ \\
\hline
\end{tabular}

Apabila dilihat dari frekuensi yang muncul dari setiap frekuensi atau jumlah peserta didik yang mencul pada tiap kategori, maka dapat diketahui bahwa motivasi peserta didik SMK Giri Pandawa terhadap motivasi pembelajaran Pendidikan, Jasmani, Olaharaga dan Kesehatan di masa pandemi covid-19 berada dalam kategori sangat tinggi.

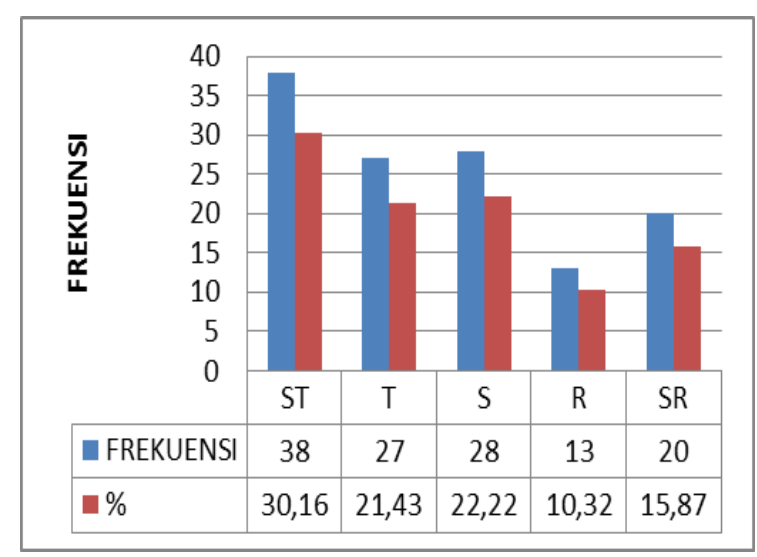

Gambar 2. Grafik Motivasi Peserta Didik SMK Giri Pandawa Terhadap Pembelajaran Pendidikan, Jasmani, Olaharaga dan Kesehatan di Masa Pandemi Covid-19

\section{Pembahasan Hasil Penelitian}

Proses pembelajaran daring saat ini sangat banyak yang perlu di perbaiki dan harus beradaptasi dengan kebiasaan baru di dalam proses pembelajaran karena proses pembelajaran daring dan tatap muka sangat jauh berbeda di harapkan guru dan peserta didik cepat untuk beradaptasi dengan kebiasaan baru ini supaya proses pembelajaran tetap bisa berlangsung, dan pembelajaran daring memerlukan suatu pedekatan yang berbeda dalam hal perencanaan, perancangan, penyampaian kusus dan komunikasi. Di samping itu guru harus mengembangkan dan menggunakan metode-metode dan gaya pembelajaran baru, mulai dari intruksi langsung hingga mengelola pembelajaran secara baik, memberi dukungan terhadap peserta didik, memfasilitasi perdebatan jarak jauh, serta mendeseminasi informasi dan pandangan-pandangan. Hal tersebut sejalan dengan penelitian yang dilakukan oleh Eka et al., (2020) yang menyatakan pembelajaran jarak jauh yang pelaksananaya secara online pastinya memiliki tantangan tersendiri bagi guru PJOK dan juga siswa yang biasanya aktivitas pembelajaran lebih dominan dilakukan di luar ruangan atau di lapangan olahraga, dimana saat ini harus dilaksanakan di rumah secara mandiri.

Namun, dilihat dari mata pelejaran PJOK yang sebagaian besar berhubungan dengan fisik siswa sangatlah tidak relevan jika dibelajarkan melalui belajar di rumah. Hal tersebut sejalan dengan penelitian yang dilakukan oleh Herlina \& Suherman, (2020) yang menyatakan mata pelajaran PJOK khususnya pada materi yang berhubungan dengan gerakan fisik, sepintas tidak cocok jika dibelajarkan dengan model distancing learning. Pembelajaran yang memadukan antara teori dan praktik sebagaimana pada mata pelajaran PJOK, dapat menggunakan 
bantuan video, grup whatsap maupun gogle clasroom yang mudak diakses baik dari guru maupun siswa. Hal tersebut sejalan dengan Herlina et al., (2019) Flatform pembelajaran online yang paling mudah diakses dengan perangkat berbasis android misalnya aplikasi pembelajaran yang tersedia pada google. Dalam hal ini teori diberikan melalui materi online dan praktiknya dapat dilakukan di rumah dengan didokumentasikan lewat video pembelajaran pada saat tatap muka. Hal tersebut sesuai dengan penelitian lain dilakukan oleh Soni (2018) dengan penggunaan google classroom dalam kegiatan pembelajaran akan dapat menjadi efektif, jika guru dan siswa dapat mengikuti kegiatan pembelajaran secara tatap muka dengan google classroom.

Setelah melakukan analisis deskriptif kuantitatif, hasilnya menunjukan bahwa motivasi peserta didik SMA/SMK di Kecamatan Rendang terhadap pembelajaran Pendidikan Jasmani, Olahraga, dan Kesehatan di Masa Pandemi Covid-19 yaitu 51 orang $(20,16 \%)$ memiliki motivasi yang sangat tinggi, 78 orang $(30,83 \%)$ memiliki motivasi yang tinggi, 52 orang $(20,55 \%)$ memiliki motivasi yang sedang, 45 orang $(17,79 \%)$ memiliki motivasi yang rendah, dan 27 orang $(10,67 \%)$ memiliki motivasi yang sangat rendah. Hasil ini menunjukkan bahwa motivasi peserta didik SMA/SMK di Kecamatan Rendang terhadap pembelajaran Pendidikan Jasmani, Olahraga, dan Kesehatan di Masa Pandemi Covid-19 berada di kategori tinggi.

Tingginya motivasi peserta didik dalam mengikuti kegiatan pembelajaran Pendidikan Jasmani, Olahraga, dan Kesehatan di Masa Pandemi Covid-19 disebabkan oleh karena pengemasan materi yang diberikan oleh guru sangat menarik baik dari video maupun dengan menggunakan media aplikasi lainya seperti zoom. Motivasi setiap peserta didik sangat di pengaruhi oleh dua faktor yaitu faktor dalam diri dan luar diri adapun faktor dari dalam diri peserta didik tersebut meliputi pengetahuan, fasilitas, dan minat, sedangkan faktor dari luar peserta didik yaitu guru, teman, sarana prasarana, dan orang tua. Dengan adanya pengaruh dari luar maupun dari dalam diri peserta didik, akan menjadi pendorang bagi peserta didik untuk bergerak melakukan sesuatu. Faktor dari dalam dan dari luar sangat mempengaruhi tingkat motivasi peserta didik terhadap sesuatu seperti dalam mengikuti pembelajaran Pendidikan Jasmani, Olahraga, dan Kesehatan di Masa Pandemi Covid-19. Hal tersebut sejalan dengan penelitian yang dilakukan oleh (Tri Wibowo, n.d.) yang menyatakan bahwa motivasi belajar siswa dalam pembelajaran PJOK siswa kelas XI SMA/MA/SMK Negeri Se-Kecamatan Kota Ponorogo untuk nilai persentase skor motivasi belajar keseluruhan didapat hasil $77,968 \%$ dan dalam kriteria persentase termasuk kategori tinggi. Selain itu Bhetharem \& Tuasikal (2020) yang menyatakan aktivitas jasmani yang diisi dengan tugas mengerjakan latihan soal yang telah di siapkan oleh guru PJOK melalui google classroom, di masa pendemi ini dapat meningkatkan motivasi siswa dalam mengerjakan soal-soal yang diberikan. Selain itu penelitian Herlina \& Suherman (2020) menyatakan pembelajaran PJOK yang dilakukan melaui daring dengan materi yang dikemas berupa video siswa dapat memperaktikan langsung dirumah bersama dengan keluarga yang akan membuat siswa tersebut nyaman belajar di rumah dan membuat motivasi siswa meningkat dengan sangat tinggi. Kemudian penelitian Manalu \& Nainggolan (2020) menyatakan hasil penelitian yang ditemukan bahwa dengan pengaplikasian zoom sebagai pendukung pembelajaran online ratarata hasil belajar siswa lebih tinggi jika dibandingkan dengan tanpa menggunakan aplikasi zooming 
Adapun kendalan-kendala dan kesiapan guru dan sekolah di dalam pembelajaran daring yaitu Dari hasil wawancara bersama kepala sekolah SMA/SMK di Kecamatan Rendang mendapat pendapat bahwa dalam proses pembelajaran daring saat ini sangat banyak yang perlu di perbaiki dan harus beradaptasi dengan kebiasaan baru di dalam proses pembelajaran karena proses pembelajaran daring dan tatap muka sangat jauh berbeda di harapkan guru dan peserta didik cepat untuk beradaptasi dengan kebiasaan baru ini supaya proses pembelajaran tetap bisa berlangsung, dan pembelajaran daring memerlukan suatu pedekatan yang berbeda dalam hal perencanaan, perancangan, penyampaian kusus dan komunikasi. untuk kesiapan sekolah dalam menghadapi pembelajaran daring, sekolah sudah siap dari melakukan penyuluhan kepada guru-guru supaya di dalam proses pembelajaran daring ini dapat membuat inovasi supaya proses pembelajaran berlangsung lancar dan memberikan kuota gratis kepada setia peserta didik meski tidak rutin setiap bulanya. Dan bedasarkan hasil wawancara bersama guru PJOK di SMA/SMK di Kecamatan Rendang terkait kendala-kendala dan kesiapan saat pembelajaran daring, terlihat bahwa guru mengalami kesulitan atau kendala dalam pembelajaran yang di alami saat kegiatan pembelajaran daring yaitu masih sulitnya membuat materi supaya proses pembelajaran mudah di mengerti oleh peserta didik karena proses pembelajaran daring dan tatap mukan sangat jauh berbeda di pembelajaran daring peserta didik sangat gampang untuk bosan, dan sistem pembelajaran daring sering terkendala di jaringan proses pembelajaran daring dapat berjalan efektif jika jaringan internet bagus belum lagi ada pesertadidik yang membuat alasan yang mengada-ada.

\section{PENUTUP \\ Simpulan}

Berdasarkan hasil analisis data dan pembahasan dapat diambil kesimpulan, bahwa motivasi mengikuti pembelajaran Pendidikan Jasmani, Olahraga, dan Kesehatan peserta didik SMA/SMK di Kecamatan Rendang di Masa Pandemi Covid-19 berada pada kategori "tinggi". Dari hasil dan pembahasan pada penelitian ini di harapkan dapat menjadi masukan sekaligus memacu semagat belajar peserta didik dalam pembelajaran daring. Sekolah dan guru diharapkan mampu menumbuhkan motivasi peserta didik dalam proses pembelajaran daring dengan memperhatikan faktor-faktor pendukung peningkatan motivasi peserta didik.

\section{DAFTAR PUSTAKA}

Anugrahana, A. (2020). Hambatan, Solusi dan Harapan: Pembelajaran Daring Selama Masa Pandemi Covid-19 Oleh Guru Sekolah Dasar. Jurnal Scholaria, 10(3), 282-289.

\section{Arifa, F. N. (2020). TANTANGAN PELAKSANAAN KEBIJAKAN BELAJAR DARI RUMAH DALAM MASA DARURAT COVID-19.}

Arifianto, I., \& Raibowo, S. (2020). Journal STAND: Sports and Development. 1 , 49-55.

http://jurnal.unipasby.ac.id/index.php/ stand/about/submissions.

Bhetharem, I. M., Mahardika, I. M. S. U., \& Tuasikal, A. R. S. (2020). Tingkat Motivasi Dan Model Aktivitas Jasmani Siswa Dan Guru SMAN 2. Jurnal IImiah Mandala Education, 6(2), 449-455.

Cahyani, A., Listiana, I. D., \& Larasati, S. P. D. (2020). Motivasi Belajar Siswa SMA pada Pembelajaran Daring di 
Masa Pandemi Covid-19. IQ (IImu AlQur'an): Jurnal Pendidikan Islam, 3(01), 123-140. https://doi.org/10.37542/iq.v3i01.57.

Emda, A. (2018). Kedudukan Motivasi Belajar Siswa Dalam Pembelajaran. Lantanida Journal, 5(2), 172. https://doi.org/10.22373/lj.v5i2.2838

Fauziah, A., Rosnaningsih, A., \& Azhar, S. (2017). Hubungan Antara Motivasi Belajar Dengan Minat Belajar Siswa Kelas Iv Sdn Poris Gaga 05 Kota Tangerang. Jurnal JPSD (Jurnal Pendidikan Sekolah Dasar), 4(1), 47. https://doi.org/10.26555/jpsd.v4i1.a9 594

Fitriyani, Y., Fauzi, I., \& Sari, M. Z. (2020). Motivasi Belajar Mahasiswa Pada Pembelajaran Daring Selama Pandemik Covid-19. Profesi Pendidikan Dasar, 7(1), 121-132. https://doi.org/10.23917/ppd.v7i1.109 73

Hendri,Gus.Aziz, I. (2020). Motivasi siswa dalam proses pembelajaran pendidikan jasmani olahraga kesehatan 1,2. Patriot, 2, 171-181.

Herlina, Acim, Misnah, \& Khairunnisa, R. (2019). NEED ANALYSIS OF USE GOOGLE FORM FOR LEARNING IN PGSD FKIP TADULAKO UNIVERSITY. Jurnal Dikdas, 7(2), 143-150.

Herlina, H., \& Suherman, M. (2020). Potensi Pembelajaran Pendidikan Jasmani Olahraga Dan Kesehatan (Pjok) Di Tengah Pandemi Corona Virus Disease (Covid)-19 Di Sekolah Dasar. Tadulako Journal Sport Sciences And Physical Education, 8(1), $\quad 1-7$. http://jurnal.untad.ac.id/jurnal/index.p hp/PJKR/article/view/16186
Imania, K. A., \& Bariah, S. K. (2019). Rancangan Pengembangan Instrumen Penilaian Pembelajaran Berbasis Daring. Jurnal Petik, 5(1), 31-47.

https://doi.org/10.31980/jpetik.v5i1.4 45

Jasmani, P., Dan, O., Pada, K., Kelas, S., Di, K., Jatilangkung, S. D. N., Jasmani, S.-P., Rekreasi, K., \& Keolahragaan, F. I. (n.d.). Perbandingan Motivasi Siswa Dalam Mengikuti Pembelajaran. 231-235.

Jayul, A., \& Irwanto, E. (2020). Model Pembelajaran Daring Sebagai Alternatif Proses Kegiatan Belajar Pendidikan Jasmani di Tengah Pandemi Covid-19 Achmad. Jurnal Pendidikan Kesehatan Rekreasi, 6(2), 190-199.

M., S. A. (2016). Interaksi \&Motivasi Belajar Mengajar. In Interaksi \& Motivasi Belajar Mengajar (pp. 7384-85).

Muhammad, R., Saefulmilah, I., \& Saway, M. H. M. (2020). HAMBATANHAMBATAN PADA PELAKSANAAN PEMBELAJARAN DARING DI SMA RIYADHUL JANNAH JALANCAGAK SUBANG. HAMBATAN-HAMBATAN $P A D A$ PELAKSANAAN PEMBELAJARAN DARING DI SMA RIYADHUL JANNAH JALANCAGAK SUBANG Rd., 2(November), 393404.

https://ejournal.stitpn.ac.id/index.php/ nusantara

Mustofa, M. I., Chodzirin, M., Sayekti, L., \& Fauzan, R. (2019). Formulasi Model Perkuliahan Daring Sebagai Upaya Menekan Disparitas Kualitas Perguruan Tinggi. Walisongo Journal of Information Technology, 1(2), 151. https://doi.org/10.21580/wjit.2019.1.2 .4067 
Nopiyanto, Y. E., Raibowo, S., \& Suryatama, R. Y. (2019). HAMBATAN GURU PENDIDIKAN JASMANI GENERASI 80-AN DALAM PEMBELAJARAN DARING DI TENGAH PANDEMI COVID-19. Journal of Chemical Information and Modeling, 53(9), 1689-1699.

Oknisih, N., Wahyuningsih, Y., \& Suryoto. (2019). Penggunaan Aplen (aplikasi online ) sebagai upaya kemandirian belajar siswa. Seminar Nasional Pendidikan Dasar, 477-483.

Oktawirawan, D. H. (2020). Faktor Pemicu Kecemasan Siswa dalam Melakukan Pembelajaran Daring di Masa Pandemi Covid-19. Jurnal IImiah Universitas Batanghari Jambi, 20(2), 541. https://doi.org/10.33087/jiubj.v20i2.9 32

Pakpahan, R., \& Fitriani, Y. (2020). JISAMAR (Journal of Information System, Applied, Management, Accounting and Researh). 4(2), 3036.

Rigianti, H. A. (2020). No KENDALA PEMBELAJARAN DARING GURU SEKOLAH DASAR DI KABUPATEN BANJARNEGARA. 2507(1), 1-9.

Sadikin, A., \& Hamidah, A. (2020). Pembelajaran Daring di Tengah Wabah Covid-19. Biodik, 6(2), 109119.

https://doi.org/10.22437/bio.v6i2.975 9

Samsudin. (2008). Pembelajaran Pendidikan Jasmani Olahraga dan Kesehatan SMP/MTs (Issue May 2016, pp. 1-241).
Saputra, H. D., Ismet, F., \& Andrizal, A. (2018). Pengaruh Motivasi Terhadap Hasil Belajar Siswa SMK. INVOTEK: Jurnal Inovasi Vokasional Dan Teknologi, 18(1), 25-30. https://doi.org/10.24036/invotek.v18i 1.168

Setiawan, M. A. (1999). Belajar dan Pembelajaran. In PT. Rineka Cipta, Jakarta (p. 298 halaman).

Siti Suprihatin, P. (2019). Upaya Meningkatkan Motivasi Belajar Siswa. G-Couns: Jurnal Bimbingan Dan Konseling, 3(1), 73-82. https://doi.org/10.31316/g.couns.v3i1 .89

Soni, Hafid, A., Hayami, R., Fatma, Y., Wenando, F. A., Amien, J. Al, Fuad, E., Unik, M., Mukhtar, H., \& Hasanuddin. (2018). Optimalisasi Pemanfaatan Google Classroom Sebagai Media Pembelajaran Di SMK Negeri 1 Bangkinang. Jurnal Pengabdian Untuk Mu NegeRI, 2(1), 17-20.

https://www.researchgate.net/publica tion/331703602\%0AOPTIMALISASI

Sulfemi, W. B. (2018). Hubungan Motivasi Belajar Dengan Hasil Belajar Ips Di Smp Kabupaten Bogor. Edutecno, 18(106), 1-12. https://doi.org/10.31227/osf.io/eqczf

Tri Wibowo, B. F. T. K. (n.d.). SURVEI MOTIVASI BELAJAR SISWA DALAM MENGIKUTI PEMBELAJARAN JASMANI, OLAHRAGA DAN KESEHATAN PADA SISWA SMA/MA/SMK NEGERI KELAS XI SEKECAMATAN KOTA PONOROGO. 117-122. 